\title{
ПОТРЕБИ УЧАСНИКІВ АНТИТЕРОРИСТИЧНОЇ ОПЕРАЦІї 3 ІНВАЛІДНІСТЮ ВНАСЛІДОК СОМАТИЧНОЇ ПАТОЛОГІЇ В ТЕХНІЧНИХ ЗАСОБАХ РЕАБІЛІТАЦІЇ ТА ВИРОБАХ МЕДИЧНОГО ПРИЗНАЧЕННЯ
}

\author{
${ }^{1}$ Науково-дослідний інститут реабілітації осіб з інвалідністю Вінницького національного медичного \\ університету імені М. І. Пирогова, м. Вінниця, Україна \\ ${ }^{2}$ Міська клінічна лікарня № 3, м. Вінниця, Україна \\ ${ }^{3}$ Вінницький обласний центр медико-соціальної експертизи, м. Вінниця, Україна
}

\begin{abstract}
Мета: визначити потреби учасників антитерористичної операції з інвалідністю внаслідок соматичної патології в технічних засобах реабілітації та виробах медичного призначення.

Матеріали і методи. На основі аналізу індивідуальних програм реабілітації, розроблених медико-соціальними експертними комісіями 19 областей України, розраховані показники потреб учасників антитерористичної операції з інвалідністю внаслідок соматичної патології в технічних засобах реабілітації та виробах медичного призначення.

Результати. У структурі заходів медико-соціальної реабілітації учасникам антитерористичної операції 3 інвалідністю рекомендації щодо технічних засобів склали 2,3 \%, медичних виробів - 0,1%. Загалом було призначено 327 рекомендацій із засобів реабілітації (в середньому на одну особу - 0,17) та 31 рекомендацію 3 медичних виробів $(0,016)$. Серед технічних засобів найбільшою була потреба у засобах пересування та протезних виробах; у осіб старших 60 років та з інвалідністю I групи; у Тернопільській області та м. Києві; при хворобах кістково-м'язової та нервової систем. Серед медичних виробів - у гігієнічних засобах для догляду, наборах для аортокоронарного шунтування; у хворих молодого віку та осіб з інвалідністю I групи; в Івано-Франківській області; при хворобах вуха та соскоподібного відростка.

Висновки. Визначення особливостей потреб учасників антитерористичної операції з інвалідністю внаслідок соматичної патології у технічних засобах реабілітації та виробах медичного призначення залежно від віку, тяжкості інвалідності, виду засобу (виробу), регіональної належності є організаційно-методичною основою для удосконалення системи медико-соціальної реабілітації таких осіб як у цілому, так і на регіональному рівні.
\end{abstract}

КЛЮЧОВІ СЛОВА: особи з інвалідністю; учасники антитерористичної операції; соматична патологія; технічні засоби реабілітації; вироби медичного призначення; потреби.

За умов війни, яка триває на сході України, реабілітація військовослужбовців має загальнодержавне значення, $€$ важливою складовою обороноздатності країни. Вдосконалення системи надання медичної та соціальної допомоги, включно забезпечення технічними засобами реабілітації та виробами медичного призначення осіб з інвалідністю внаслідок бойових дій (БД) під час антитерористичної операції (АТО), на сьогодні $€$ найактуальнішим завданням, тому що кожен п'ятий поранений в ході БД на сході України має вторинну, пов'язану 3 бойовою травмою (БТ), патологію внутрішніх органів, якій притаманні малосимптомність, пізнє виявлення, схильність до рецидивів та ускладнень, тяжкий перебіг, коморбідність, часте поєднання з черепно-мозковою та торакоабдомінальною травмами, невідповідність ступеня функціональних порушень патоморфологічним змінам в органах [3]. В учасників АTO спостерігали ознаки вегетативної диссрункції (68,9 \%) $[1,4]$, анемію (36,2 \%), метаболічну кардіоміопатію
(15,4 \%), патологію сечовидільної системи (2,7 \%), органів дихання (2 \%) [3], гепатопатію (10 \%) [8], погіршувався стан систолічної та діастолічної функцій лівого шлуночка [9], частіше діагностували бронхіальну астму [2], пневмонію, міокардит, перикардит, нефрит [5], миготливу аритмію, IXC, ранні інфаркти міокарда. В структурі захворювань хвороб органів травлення переважають (72,9 \%) кислотозалежні захворювання з ерозивно-виразковими ушкодженнями езофрагогастродуоденальної зони [6].

На ризик настання інвалідності внаслідок БД впливають ряд чинників, серед яких - характер отриманої БТ, ступінь її тяжкості, вік отримання, вид наданої медичної допомоги, фракт госпіталізації тощо [7]. Порушення фрункцій зумовлюють переважно обмеження самообслуговування, пересування і здатності до праці, при виражених і значно виражених порушеннях - здатності до навчання, спілкування і орієнтації.

Технічні та інші засоби реабілітації (ТЗР) та вироби медичного призначення (ВМП) відіграють

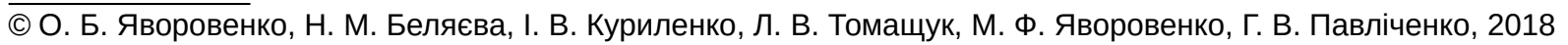


значну роль в адаптації учасників АТО з інвалідністю та їх інтеграції в суспільство.

Мета дослідження: визначити потреби учасників антитерористичної операції 3 інвалідністю внаслідок соматичної патології, яка виникла або загострилась під час бойових дій, в технічних засобах реабілітації та виробах медичного призначення.

Матеріали і методи. Проведено дослідження діяльності медико-соціальних експертних комісій (МСЕК) із формування індивідуальних програм реабілітації (IПР) учасникам АТО з інвалідністю внаслідок соматичної патології, розраховані показники потреб у ТЗР та ВМП, а також залежно від віку, тяжкості інвалідності, видів ТЗР та ВМП та регіональної належності.

Проведено вивчення IПР та розрахунок показників потреб 1900 учасникам АТО з інвалідністю внаслідок соматичної патології: хвороб кістковом'язової системи та сполучної тканини (далі-хвороби КМС) (М00-М99), нервової системи (далі HC) (G00-G99), системи кровообігу (I00-199), органів дихання (J00-J99), травлення (К00-К93), сечостатевої системи (N00-N99), ендокринних хвороб, розладів харчування та порушень обміну речовин (далі - ендокринних хвороб) (Е00-Е90), новоутворень (C00-D48), деяких інфекційних та паразитарних хвороб (далі - інфрекційних хвороб) (А00-В99), ока та його придаткового апарату (далі - ока) (Н00-Н59), вуха та соскоподібного відростка (далі - вуха) (Н60-Н95). Дослідження проводили за даними 2016 р. у 19 областях України. Використано методи: мета-аналіз за даними ІПР, статистичний, аналітичний, експертних оцінок. Обробку матеріалу проводили 3 використанням методів математичної статистики за допомогою програмного пакета СКМ Maple 15.

Результати дослідження та їх обговорення. Виявлено, що при соматичній патології 1900 учасникам АТО з інвалідністю в ІПР було рекомендовано 10570 медико-соціальних послуг, в їх структурі рекомендації з ТЗР (рекомендовано 327 засобів) склали 2,3 \%, ВМП (рекомендовано 31 виріб) - 0,1 \% (рис. 1).

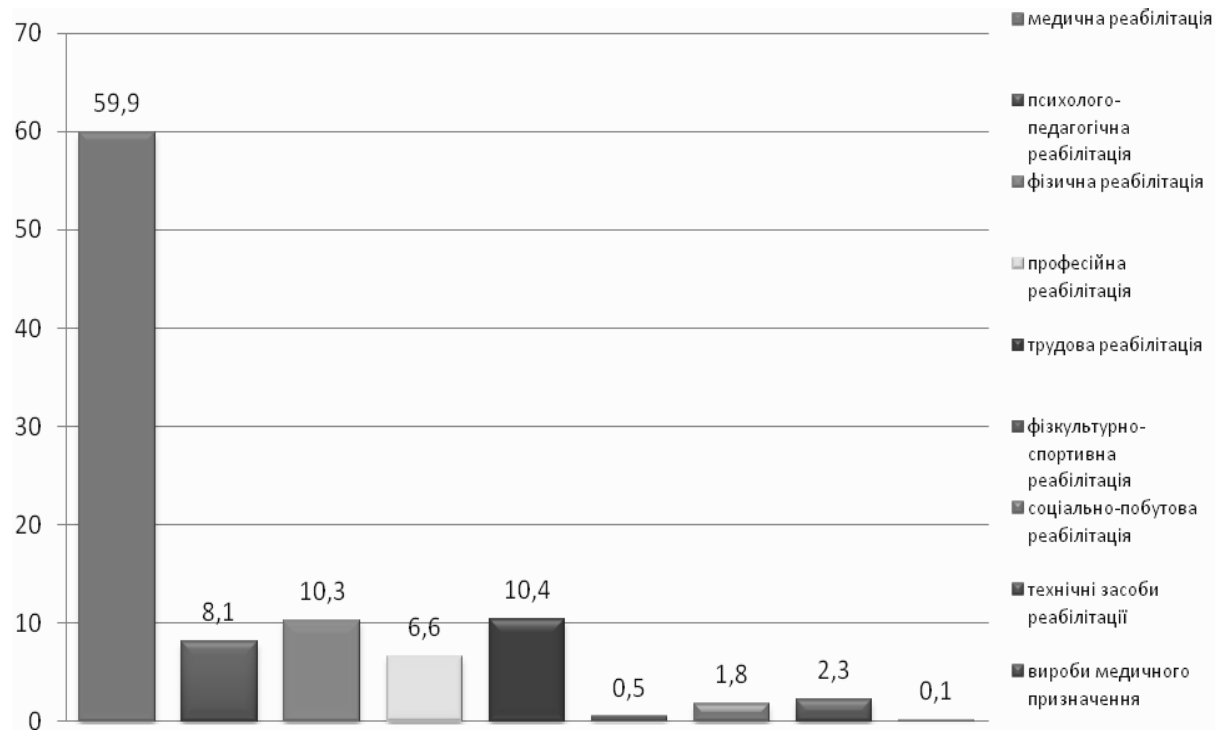

Puc. 1. Загальна структура заходів медико-соціальної реабілітації при соматичній патології в учасників АТО з інвалідністю (\%).

Найбільше ТЗР було призначено при хворобах КМС - 156, хворобах системи кровообігу - 74, хворобах НС - 39, новоутвореннях та хворобах органів травлення - по 23, хворобах ока - 8, ендокринних хворобах - 4; інфекційних хворобах, хворобах вуха, органів дихання та сечостатевої системи ТЗР не призначали. У середньому на одну особу припадало 0,17 рекомендацій з ТЗР.

Потреба учасників АТО з інвалідністю внаслідок соматичної патології в ТЗР загалом склала 17,2 (табл. 1). Найбільшою вона була при хворобах КМC $(47,0)$, НC $(30,7)$ та новоутвореннях $(22,3)$, дещо менше - при хворобах органів травлення $(18,3)$, ока $(14,5)$, системи кровообігу $(12,8)$, ендокринних хворобах $(5,9)$. За видом ТЗР найбільшою була потреба в засобах пересування $(7,0)$ та протезних виробах $(6,2)$; потреба у засобах для догляду склала 2,5, у фрізкультурно-спортивному обладнанні - 1,1; потреба у решті видів ТзР була незначною. У засобах пересування потреба була найбільшою при хворобах НC $(22,0)$, у засобах для орієнтування - при хворобах ока $(7,3)$, засобах для самообслуговування, а також у фрізкультурно-спортивному обладнанні - при новоутвореннях (1,9 та 4,9 відповідно), засобах для догляду, а також засобах для освіти - при хворобах НС (6,3 та 0,8 відповідно), у протезних виробах - при хворобах КMC $(25,3)$. 
Таблиця 1. Потреба учасників АТО з соматичною патологією в ТЗР залежно від нозології (у \% до кількості осіб)

\begin{tabular}{|c|c|c|c|c|c|c|c|c|}
\hline & \multirow[b]{2}{*}{$\begin{array}{c}\text { T3Р } \\
\text { (усього) }\end{array}$} & \multicolumn{7}{|c|}{ Вид ТЗР } \\
\hline & & 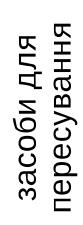 & 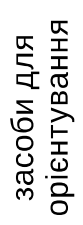 & 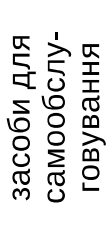 & 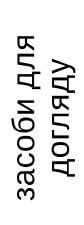 & 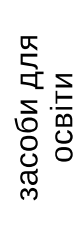 & 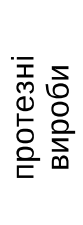 & 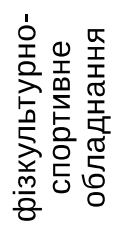 \\
\hline Деякі інфекційні та паразитарні хвороби & - & - & - & - & - & - & - & - \\
\hline Новоутворення & 22,3 & 6,8 & - & 1,9 & 4,9 & - & 3,9 & 4,9 \\
\hline Ендокринні хвороби & 5,9 & 2,9 & - & - & 1,5 & - & 1,5 & - \\
\hline Хвороби нервової системи & 30,7 & 22,0 & - & - & 6,3 & 0,8 & 1,6 & - \\
\hline Хвороби ока та його придаткового апарату & 14,5 & - & 7,3 & - & 3,6 & - & 3,6 & - \\
\hline Хвороби вуха та соскоподібного відростка & - & - & - & - & - & - & - & - \\
\hline Хвороби системи кровообігу & 12,8 & 4,5 & - & 0,2 & 4,1 & 0,2 & 1,7 & 2,1 \\
\hline Хвороби органів дихання & - & - & - & - & - & - & - & - \\
\hline Хвороби органів травлення & 18,3 & 7,1 & - & - & - & - & 11,1 & - \\
\hline Хвороби КМС та сполучної тканини & 47,0 & 18,4 & - & - & 2,1 & - & 25,3 & 1,2 \\
\hline Хвороби сечостатевої системи & - & - & - & - & - & - & - & - \\
\hline Усього & 17,2 & 7,0 & 0,2 & 0,2 & 2,5 & 0,1 & 6,2 & 1,1 \\
\hline
\end{tabular}

Потреба в засобах для пересування, самообслуговування, догляду була найбільшою в осіб, старших 60 років, у протезних виробах та засобах для орієнтування - в осіб молодого віку, в засобах для освіти та фрізкультурно-спортивному обладнанні в осіб середнього віку (табл. 2). Майже у всіх видах ТзР потреба була найбільшою у осіб з інвалідністю I групи і лише у фрізкультурно-спортивному обладнанні - у осіб з II групою інвалідності.

По регіонах найбільшою потреба в ТЗР виявилась у Тернопільській області та м. Києві, найменшою - у Житомирській, Закарпатській, Херсонській та Хмельницькій областях (тут ТЗР не призначали) (табл. 3). Потреба у засобах для пересування була найбільшою у Тернопільській,
Рівненській та Харківській областях, у протезних виробах - у Тернопільській області, засобах для догляду - в Миколаївській та Харківській. Потреба у засобах для орієнтування була виявлена лише у Вінницькій області, освіти - у Харківській, самообслуговування - в Тернопільській, Харківській областях та м. Києві, у фрізкультурно-спортивному обладнанні - в м. Києві та Івано-Франківській області.

Найбільшою потреба в ТЗР при хворобах НС була в Миколаївській області, при новоутвореннях - в Тернопільській, хворобах ока - у Вінницькій, хворобах системи кровообігу - в м. Києві, органів травлення - в Полтавській області, хворобах КМС - у Львівській та Тернопільській

Таблиця 2. Потреба учасників АТО з соматичною патологією в ТЗР залежно від віку та тяжкості інвалідності (у \% до кількості осіб)

\begin{tabular}{|c|c|c|c|c|c|c|c|}
\hline \multirow{3}{*}{ Вид ТЗР } & \multirow{3}{*}{$\begin{array}{l}\text { Усього } \\
\text { ТЗР }\end{array}$} & \multicolumn{6}{|c|}{ У тому числі за: } \\
\hline & & \multicolumn{3}{|c|}{ віком } & \multicolumn{3}{|c|}{ групою інвалідності } \\
\hline & & $18-44$ & $45-60$ & $61 \mathrm{i}>$ & І гр. & II гр. & III гр. \\
\hline Засоби для пересування & 7,0 & 5,6 & 8,5 & 10,0 & 34,4 & 7,2 & 5,7 \\
\hline $\begin{array}{l}\text { Засоби для орієнтування, спілкування } \\
\text { та обміну інфрормацією }\end{array}$ & 0,2 & 0,4 & - & - & 6,6 & - & - \\
\hline Засоби для самообслуговування & 0,2 & 0,1 & 0,1 & 5,0 & 4,9 & - & - \\
\hline Засоби для догляду & 2,5 & 1,6 & 3,0 & 20,0 & 36,1 & 4,0 & 0,6 \\
\hline $\begin{array}{l}\text { Засоби для освіти і занять трудовою } \\
\text { діяльністю }\end{array}$ & 0,1 & - & 0,2 & - & 3,3 & 0,2 & - \\
\hline Протезні вироби & 6,2 & 6,4 & 5,9 & 5,0 & 14,8 & 5,8 & 5,9 \\
\hline $\begin{array}{l}\text { Спеціальне фрізкультурно-спортивне } \\
\text { обладнання і спорядження }\end{array}$ & 1,1 & - & 2,4 & - & - & 2,8 & 0,6 \\
\hline Усього & 17,2 & 14,2 & 20,1 & 40,0 & 100,0 & 19,8 & 12,8 \\
\hline
\end{tabular}


Таблиця 3. Потреба учасників АТО з соматичною патологією в ТЗР по регіонах (у \% до кількості осіб)

\begin{tabular}{|c|c|c|c|c|c|c|c|c|}
\hline \multirow[b]{2}{*}{ Області } & \multirow[b]{2}{*}{$\begin{array}{c}\text { Усього } \\
\text { ТЗР }\end{array}$} & \multicolumn{7}{|c|}{ За видами ТЗР } \\
\hline & & 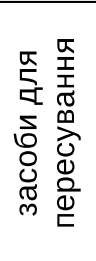 & 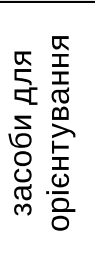 & 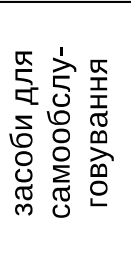 & 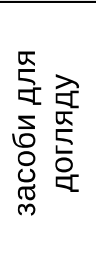 & 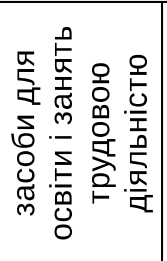 & 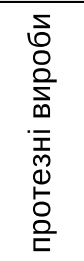 & 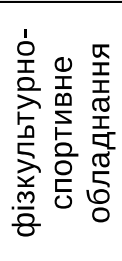 \\
\hline Вінницька & 16,7 & 2,1 & 2,8 & - & - & - & 11,8 & - \\
\hline Волинська & 1,2 & 1,2 & - & - & - & - & - & - \\
\hline Житомирська & - & - & - & - & - & - & - & - \\
\hline Закарпатська & - & - & - & - & - & - & - & - \\
\hline Івано-Франківська & 9,5 & 4,2 & - & - & 1,1 & - & - & 4,2 \\
\hline Київська & 17,1 & 13,8 & - & - & - & - & 3,3 & - \\
\hline Кіровоградська & 10,9 & 9,4 & - & - & 1,6 & - & - & - \\
\hline Львівська & 21,5 & 10,2 & - & - & 1,6 & - & 9,8 & - \\
\hline Миколаївська & 33,6 & 4,8 & - & - & 20,8 & - & 8,0 & - \\
\hline Одеська & 14,0 & 7,0 & - & - & - & - & 7,0 & - \\
\hline Полтавська & 20,0 & 8,6 & - & - & - & - & 11,4 & - \\
\hline Рівненська & 17,5 & 15,0 & - & - & - & - & 2,5 & - \\
\hline Сумська & 23,1 & 7,7 & - & - & 2,6 & - & 12,8 & - \\
\hline Тернопільська & 57,6 & 15,3 & - & 1,7 & 3,4 & - & 37,3 & - \\
\hline Харківська & 33,3 & 15,0 & - & 1,7 & 10,0 & 3,3 & 3,3 & - \\
\hline Херсонська & - & - & - & - & - & - & - & - \\
\hline Хмельницька & - & - & - & - & - & - & - & - \\
\hline Чернігівська & 14,1 & 4,2 & - & - & - & - & 9,9 & - \\
\hline М. Київ & 37,0 & 6,5 & - & 1,1 & 6,5 & - & 4,3 & 18,5 \\
\hline Усього & 17,2 & 7,0 & 0,2 & 0,2 & 2,5 & 0,1 & 6,2 & 1,1 \\
\hline
\end{tabular}

областях. При інфекційних хворобах, хворобах органів дихання, сечостатевої системи, вуха потреб у призначенні ТЗР не було.

При хворобах НС, крім потреби у засобах для пересування, спостерігали також потребу в засобах для догляду $(6,3)$, протезних виробах $(1,6)$, засобах для освіти $(0,8)$. Найбільші потреби спостерігали в осіб середнього віку (за рахунок засобів для пересування, проте у засобах для догляду найбільшу потребу мали особи молодого віку) та в осіб з інвалідністю I групи; по регіонах - у Львівській області (за рахунок засобів для догляду та для пересування), натомість у 14 областях України ТЗР особам $з$ інвалідністю не призначали.

При хворобах КМС, крім потреби у протезних виробах, учасники АТО потребували засобів для пересування (показник 18,4), для догляду $(2,1$ у Миколаївській області), фрізкультурно-спортивного обладнання (1,2 в Івано-Франківській області). Найбільші потреби були в осіб середнього віку (за рахунок засобів для догляду та фрізкультурно-спортивного обладнання), проте різниця в потребах осіб середнього та молодого віку в протезних виробах та засобах для пересування була несуттєвою. Найбільшу потребу мали особи 3 інвалідністю II групи (за рахунок протезних виробів та засобів для пересування). Стовідсотковою була потреба у Львівській та Тернопільській областях, натомість в ряді регіонів (Житомирській, Закарпатській, Кіровоградській, Полтавській, Херсонській, Хмельницькій областях, м. Києві) ТЗР при цій патології взагалі не призначали. Найбільша потреба майже в усіх областях була в протезних виробах та засобах для пересування. Крім того, у Миколаївській області була потреба у засобах для догляду.

При хворобах системи кровообігу потреба в ТЗР була приблизно рівною у засобах для пересування та засобах для догляду, дещо менше - в інших ТЗР; засоби для орієнтування не призначали. Спостерігали залежність потреб від віку та тяжкості інвалідності. Найбільшою потреба в усіх ТЗР була в м. Києві, у засобах для пересування - в Кіровоградській області, засобах для догляду - в Миколаївській, протезних виробах у Тернопільській; потреба в засобах для самообслуговування та фрізкультурно-спортивному обладнанні була лише в м. Києві, у засобах для освіти - лише у Харківській області.

При новоутвореннях було призначено 23 ТЗР (засоби для пересування - 7, засоби для догляду -5 , фрізкультурно-спортивне обладнання - 5, протезні вироби - 4, засоби для самообслуговування-2); при хворобахорганів травлення-також 23 (протезні вироби - 14, засоби для пересування 
- 9); при хворобах ока - 8 (засоби для орієнтування - 4, засоби для догляду - 2, протезні вироби - 2); при ендокринних хворобах - 4 (засоби для пересування - 3, протезні вироби - 1). У середньому на одну особу з новоутвореннями припадало 0,22 послуг із ТЗР, з хворобами органів травлення - 0,18, 3 хворобами ока - 0,15, з ендокринними хворобами - 0,06. При новоутвореннях потреба була найбільшою у засобах для пересування $(6,8)$, більше у осіб, старших 60 років, та представників I групи інвалідності. При хворобах органів травлення найбільшою була потреба у протезних виробах $(11,1)$, переважно - у осіб молодого віку та 3 II групою інвалідності. Найчастіше ТЗР (протезні вироби та засоби для пересування) призначали в Полтавській області; при хворобах ока - у Вінницькій області (засоби для орієнтування, протезні вироби) та м. Києві (засоби для догляду та протезні вироби); при новоутвореннях - у м. Києві (фрізкультурно-спортивне обладнання, засоби для пересування, протезні вироби, засоби для догляду), а також - Київській, Тернопільській, Харківській та Полтавській областях; при ендокринних хворобах - лише в Сумській та Тернопільській областях (засоби для пересування, засоби для догляду, протезні вироби).

У структурі виробів медичного призначення (ВМП) найбільший відсоток склали сечоприймачі та підгузки - по 6 (19,4 \%), калоприймачі - 5 (16,1\%); також призначали набори для проведення аортокоронарного шунтування (АКШ) - 4 (12,9 \%), набори для імплантації механічного клапана серця, для проведення коронарографрії, слухові апарати та протези очей - по 2 (6,5\%), ендопротези суглобів та електрокардіостимулятори (ЕКС) - по 1 (3,2 \%). У середньому на одну особу припадало 0,016 ВМП.

Потреба учасників АТО з інвалідністю внаслідок соматичної патології у ВМП склала 1,6 (табл. 4).

Таблиця 4. Потреба учасників АТО з соматичною патологією у Вмп залежно від віку, тяжкості інвалідності (у \% до кількості осіб)

\begin{tabular}{|c|c|c|c|c|c|c|c|}
\hline \multirow{2}{*}{ Вид ВМП } & \multirow{2}{*}{ Усього } & \multicolumn{3}{|c|}{ Вік, роки } & \multicolumn{3}{|c|}{ Тяжкість інвалідності } \\
\hline & & $18-44$ & $45-60$ & $61 \mathrm{i}>$ & I гр. & II гр. & III гр. \\
\hline Сечоприймачі & 0,3 & 0,5 & 0,1 & - & 8,2 & - & 0,1 \\
\hline Калоприймачі & 0,3 & 0,5 & - & - & 8,2 & - & - \\
\hline Підгузки & 0,3 & 0,6 & - & - & 9,8 & - & - \\
\hline Протези очей & 0,1 & 0,2 & - & - & 1,6 & - & 0,1 \\
\hline Слухові апарати & 0,1 & - & 0,2 & - & - & - & 0,1 \\
\hline Набори для проведення коронарографії & 0,1 & - & 0,2 & - & 1,6 & 0,2 & - \\
\hline Електрокардіостимулятори & 0,1 & - & 0,1 & - & - & 0,2 & - \\
\hline Набори для проведення АКШ & 0,2 & 0,1 & 0,3 & - & - & - & 0,3 \\
\hline $\begin{array}{l}\text { Набори для імплантації механічного клапана } \\
\text { серця, однокамерні ШВРС із біполярним } \\
\text { електродом }\end{array}$ & 0,1 & - & 0,2 & - & - & 0,5 & - \\
\hline $\begin{array}{l}\text { Ендопротези суглобів, у тому числі } \\
\text { ендопротези суглобів із видовженням для } \\
\text { онкологічних хворих }\end{array}$ & 0,1 & 0,1 & - & - & - & - & 0,1 \\
\hline Усього & 1,6 & 1,1 & 0,6 & - & 0,9 & 0,2 & 0,5 \\
\hline
\end{tabular}

Найбільшою вона була у сечо-, калоприймачах та підгузках (по 0,3), наборах для АКШ $(0,2)$, слухових апаратах, протезах очей, наборах для імплантації механічного клапана серця, наборах для коронарограсрії, а також в ендопротезах суглобів та ЕКС (по 0,1). За віком вона була більшою у хворих молодого віку, ніж середнього (1,1 та 0,6 відповідно) - за рахунок їх більшої потреби у кало- та сечоприймачах, підгузках, ендопротезах очей та суглобів, натомість у хворих середнього віку була більшою потреба в ЕКС, наборах для імплантації механічного клапана серця, однокамерних штучних водіях ритму серця (ШВРС) 3 біполярним електродом, для коронарограсіії та АКШ. За тяжкістю інвалідності більшою була потреба в осіб з інвалідністю I групи (0,9 - проти 0,2 та 0,5 - у осіб II та III груп відповідно). Ця перевага виникла за рахунок значно більшої потреби хворих I групи у кало- та сечоприймачах та підгузках, ніж у представників більш легких груп. Натомість у осіб II та III груп, на відміну від I групи, була потреба в ЕКС, наборах для АКШ, імплантації механічного клапана серця, однокамерних ШВРС із біполярним електродом, ендопротезах суглобів. За регіональним розподілом ВМП учасникам ATO з соматичною патологією призначали лише у 8 регіонах $з$ 19. Найбільшою $(8,4)$ була потреба у ВМП в Івано-Франківській області. Особи з інвалідністю I групи мали найбільшу потребу у ВМП у Львівській області, III групи - в Івано-Франківській; хворі молодого віку - у Львівській області, середнього - в Івано-Франківській. В середньому на одну особу припадало 0,016 виробів медичного призначення. 
За класом хвороб найбільшою була потреба при хворобах вуха $(7,7)$, дещо меншою - при хворобах НС $(4,7)$, ока $(3,6)$, системи кровообігу $(2,8)$, інфекційних хворобах $(2,6)$ (табл. 5). При хворобах КМС та новоутвореннях вона складала 0,3-1,0. При ендокринних хворобах, хворобах органів дихання, травлення, сечостатевої системи медичні вироби не призначали. Привертає увагу висока потреба у ВМП при патології ока в Чернігівській області та при патології НС - у Львівській області. При хворобах системи кровообігу учасники АТО мали потребу в 4 областях, при патології ока - в 2, по кожному з інших класів хвороб відзначено потребу лише в одній з областей.

Таблиця 5. Потреба учасників АТО з соматичною патологією у ВМП по регіонах (у \% до кількості осіб)

\begin{tabular}{|c|c|c|c|c|c|c|c|c|}
\hline \multirow[b]{2}{*}{ Області } & \multicolumn{8}{|c|}{ Нозологічні форми } \\
\hline & 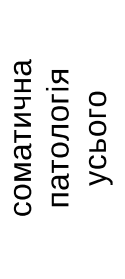 & 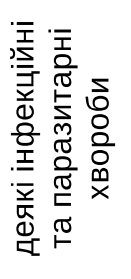 & 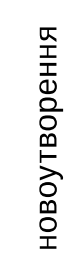 & 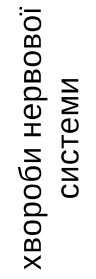 & 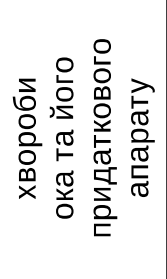 & 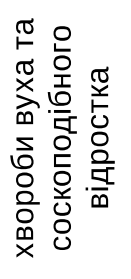 & 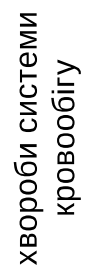 & 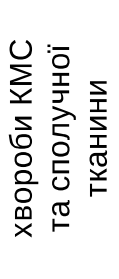 \\
\hline Вінницька & 2,8 & 33,3 & - & - & - & - & - & - \\
\hline Волинська & - & - & - & - & - & - & - & - \\
\hline Житомирська & - & - & - & - & - & - & - & - \\
\hline Закарпатська & - & - & - & - & - & - & - & - \\
\hline Івано-Франківська & 8,4 & - & - & - & - & 33,3 & - & - \\
\hline Київська & 0,7 & - & - & - & - & - & - & - \\
\hline Кіровоградська & - & - & - & - & - & - & 2,5 & - \\
\hline Львівська & 4,7 & - & - & 60,0 & - & - & - & - \\
\hline Миколаївська & - & - & - & - & - & - & 5,1 & - \\
\hline Одеська & - & - & - & - & - & - & - & - \\
\hline Полтавська & - & - & - & - & - & - & - & - \\
\hline Рівненська & - & - & - & - & - & - & - & - \\
\hline Сумська & - & - & - & - & - & - & - & - \\
\hline Тернопільська & 3,4 & - & 25,0 & - & - & - & - & - \\
\hline Харківська & 1,7 & - & - & - & - & - & 9,1 & 14,3 \\
\hline Херсонська & - & - & - & - & - & - & - & - \\
\hline Хмельницька & - & - & - & - & - & - & - & - \\
\hline Чернігівська & 1,4 & - & - & - & 100,0 & - & - & - \\
\hline М. Київ & 1,1 & - & - & - & 10,0 & - & 30,4 & - \\
\hline Усього & 1,6 & 2,6 & 1,0 & 4,7 & 3,6 & 7,7 & 2,8 & 0,3 \\
\hline
\end{tabular}

\section{Висновки}

1. Учасникам антитерористичної операції 3 інвалідністю внаслідок соматичної патології медико-соціальними експертними комісіями у 2016 р. було призначено 327 технічних засобів реабілітації та 31 виріб медичного призначення, у середньому на одну особу припадало 0,17 ТЗР та 0,016 виробів медичного призначення.

2. Потреба учасників АТО з інвалідністю внаслідок соматичної патології у технічних засобах реабілітації склала 17,2, у виробах медичного призначення $-1,6$.

3. Серед технічних засобів для реабілітації найбільшою була потреба у засобах для пересування та протезних виробах; за віком та тяжкістю інвалідності-у осіб старших 60 років та з інвалідністю I групи; за регіональним розподілом - у Тернопільській області та м. Києві; за нозологіями - при хворобах кістково-м'язової системи та сполучної тканини і при хворобах нервової системи.

4. Серед виробів медичного призначення потреба була найбільшою у сечо- та калоприймачах, підгузках, наборах для аортокоронарного шунтування; за віком та тяжкістю інвалідності - у хворих молодого віку та у осіб з інвалідністю I групи; за регіональним розподілом - в Івано-Франківській області; за нозологіями - при хворобах вуха та соскоподібного відростка.

5. Аналіз формування IПР на МСЕК показав значну розбіжність в показниках потреб осіб з інвалідністю в технічних засобах реабілітації та виробах медичного призначення в областях за нозологічними формами, видами засобів (виробів), що зумовлено відсутністю єдиного методичного 
підходу, недосконалістю роботи реабілітологів MCEК з учасниками АТО, які стали особами з інвалідністю.

6. Визначені особливості потреб учасників АТО 3 інвалідністю внаслідок соматичної патології в технічних засобах реабілітації та виробах медичного призначення залежно від віку, тяжкості інвалідності, виду засобу (виробу), регіональної належності є організаційно-методичною основою для удосконалення системи медико-соціальної реабілітації таких осіб як у цілому, так і на регіональному рівні.

Перспективи подальших досліджень. Необхідна розробка науково-обґрунтованих рекомендацій щодо фрормування комплексних програм реабілітації учасників АТО з інвалідністю, забезпечення цього контингенту технічними засобами реабілітації та виробами медичного призначення на основі визначення структури їх потреб.

\section{Список літератури}

1. Козира П. В. Характеристика адаптивної поведінки і копінг-стратегій у співробітників МВС України - учасників АТО / П. В. Козира // Медична психологія. - 2016. - Т. 11, № 4. - С. 59-65.

2. Макуха Ю. М. Особливості психологічного стану та рівня інтерлейкіну-6 у військовослужбовців хворих на бронхіальну астму, що брали участь у антитерористичній операції / Ю. М. Макуха, С. Ф. Веремчук, Є. В. Андрєєв // Актуальні проблеми клінічної та профрілактичної медицини. - 2017. - Т. 1, № 1. - С. 37-40.

3. Мы должны быть готовы : актуальное интервью (Мясников Г. В.) // Therapia. - 2015. - № 2 (95). - С. 3-6.

4. Мясников Г. В. Варіабельність серцевого ритму у учасників антитерористичної операції з бойовим післятравматичним стресовим розладом / Г. В. Мясников, С. В. Софрієнко, А. М. Шиць // Сучасні аспекти військової медицини. - 2015. Вип. 22 (1). - С. 336-344.

5. Науменко М. В. Медична реабілітація учасників антитерористичної операції при патології серцево-судинної системи: стан і перспективи розвитку у Збройних силах України / М. В. Науменко, М. М. Коваль // Сучасні аспекти військової медицини. 2015. - Вип. 22 (1). - С. 45-52.

6. Епідеміологічні й терапевтичні аспекти кислотозалежних захворювань органів травлення в учасників антитерористичної операції / Г. В. Осьодло, С. М. Прокопчук, І. М. Шевага [та ін.] // Сучасні аспекти військової медицини. - 2015. - Вип. 22 (1). C. 215-218.

7. Старовойтова И. М. О единстве экспертных подходов при осуществлении медико-социальной и военно-врачебной экспертизы / И. М. Старовойтова, К. А. Саркисов, Н. П. Потехин, Т. В. Шумейко // Медико-социальная экспертиза и реабилитация. - 2014. - № 3. - С. 53-57.

8. Мінеральний гомеостаз при функціональних порушеннях печінки у вояків антитерористичної операції із черепно-мозковою травмою легкого і середнього ступенів тяжкості / В. М. Шевага, М. Г. Семчишин, Б. В. Задорожна [та ін.] // Гепатологія. 2016. - № 3. - С. 33-42.

9. Варіабельність серцевого ритму в оцінці стану серцево-судинної системи у військовослужбовців Збройних Сил України із зони проведення антитерористичної операції з супутнім посттравматичним стресовим розладом / А. М. Шиць, В. А. Березовський, С. Є. Мостовий, О. Б. Динник // Сучасні аспекти військової медицини. - 2016. - Вип. 23. - С. 232-244.

\section{References}

1. Kozyra, P.V. (2016). Kharakterystyka adaptyvnoi povedinky i kopinh-stratehii u spivrobitnykiv MVS Ukrainy - uchasnykiv ATO [Character of adaptive behavior and coping strategies in Ukrainian Law Enforcement Officials participating in ATO]. Medychna psykholohiia - Medical Psychology, 11, 4, 59-65 [in Ukrainian].

2. Makuha, Yu.M., Veremchuk, S.F. \& Andreiev, E.V. (2017). Osoblyvosti psycholohichnoho stanu ta rivnia interleikinu-6 u viiskovosluzhbovtsiv khvorykh na bronkhialnu astmu, shcho braly uchast u antyterorystychnii operatsii [Features of psychological status and the level of interleukin- 6 in patients with bronchial asthma soldiers who participated in the antiterrorist operation]. Aktualni problemy klinichnoi ta profilaktychnoi medytsyny - Actual Problems of Clinical and Preventive Medicine, 1, 1, 37-40 [in Ukrainian].

3. Myasnikov, G.V. (2015). My dolzhny byt gotovy: Aktualnoye intervyu [We must be ready: An actual interview (Myasnikov G.V.)]. Terapiya - Therapy, 2 (95), 3-6 [in Russian].

4. Miasnikov, H.V., Sofienko, S.V. \& Shits, A.M. (2015). Variabelnist sertsevoho rytmu u uchasnykiv antyterorystychnoi operatsii z boiovym pisliatravmatychnym stresovym rozladom [Heart rate variability in the anti-terror operation combatants with combat post-traumatic stress disorder]. Suchasni aspekty viiskovoi medytsyny - Modern Aspects of Military Medicine, 22, 1, 336-344 [in Ukrainian].

5. Naumenko, M.V., \& Koval, M.M. (2015). Medychna reabilitatsiia uchasnykiv antyterorystychnoi operatsii pry patolohii sertsevosudynnoi systemy: stan i perspektyvy rozvytku u zbroinykh sylakh Ukrainy [Medical rehabilitation of anti-terror operation participants in the presence of cardiovascular pathology: state and prospects of development in the Armed Forces of Ukraine]. Suchasni aspekty viiskovoi medytsyny - Modern Aspects of Military Medicine, 22, 1, 45-52 [in Ukrainian].

6. Osiodlo, H.V., Prokopchuk, S.M. \& Shevaha, I.M. (Eds.). (2015). Epidemiolohichni i terapevtychni aspekty kyslotozalezhnykh zakhvoriuvan orhaniv travlennia $v$ uchasnykiv antyterorystychnoi operatsii [Epidemiological and therapeutic aspects of acidrelated diseases of the digestive system in anti-terror operation combatants]. Suchasni aspekty viiskovoi medytsyny-Modern Aspects of Military Medicine, 22 (1), 215-218 [in Ukrainian].

7. Starovoytova, I.M., Sarkisov, K.A., Potekhin, N.P. \& Shumeyko, T.V. (2014). O edinstve ekspertnyh podhodov pri osushchestvlenii mediko-sotsialnoy i voyenno-vrachebnoy ekspertizy [About unity of expert approaches in implementation of medico-social and 
military-medical expertise]. Mediko-sotsialnaya ekspertiza i reabilitatsiya - Medico-Social Expertise and Rehabilitation, 3 , 53-57 [in Russian].

8. Shevaha, V.M., Semchyshyn, M.H., \& Zadorozhna, B.V. (Eds.). (2016). Mineralnyi homeostaz pry funktsionalnykh porushenniakh pechinky u voiakiv antyterorystychnoi operatsii iz cherepno-mozkovoiu travmoiu lehkoho i serednoho stupeniv tiazhkosti [Mineral homeostasis in functional disorders of the liver in soldiers of antiterrorist operation with brain injury of mild and moderate severity]. Hepatolohiia - Hepatology, 3, 33-42 [in Ukrainian].

9. Shits, A.M., Berezovskyi, V.A., Mostovoy, S.E. \& Dynnyk, O.B. (2016) Variabelnist sertsevoho rytmu v otsintsi stanu sertsevo-sudynnoi systemy u viiskovosluzhbovtsiv Zbroinykh Syl Ukrainy iz zony provedennia antyterorystychnoi operatsii z suputnim posttravmatychnym stresovym rozladom [Heart rate variability in cardiovascular system assessment of military personnel of the Armed Force of Ukraine from the zone of anti-terrorist operation with concomitant post-traumatic stress disorder]. Suchasni aspekty viiskovoi medytsyny - Modern Aspects of Military Medicine, 23, 232-244 [in Ukrainian].

\section{ПОТРЕБНОСТИ УЧАСТНИКОВ АНТИТЕРРОРИСТИЧЕСКОЙ ОПЕРАЦИИ С ИНВАЛИДНОСТЬЮ ВСЛЕДСТВИЕ СОМАТИЧЕСКОЙ ПАТОЛОГИИ В ТЕХНИЧЕСКИХ СРЕДСТВАХ РЕАБИЛИТАЦИИ И ИЗДЕЛИЯХ МЕДИЦИНСКОГО НАЗНАЧЕНИЯ}

О. Б. Яворовенко ${ }^{1}$ Н. Н. Беляева ${ }^{1}$, И. В. Куриленко

${ }^{1}$ Научно-исследовательский институт реабилитации лиц с инвалидностью Винницкого национального медицинского университета имени Н. И. Пирогова, г. Винница, Украина

${ }^{2}$ Городская клиническая больница № 3, г. Винница, Украина

${ }^{3}$ Винницкий областной центр медико-социальной экспертизы, г. Винница, Украина

Цель: определить потребности участников антитеррористической операции с инвалидностью вследствие соматической патологии в технических средствах реабилитации и изделиях медицинского назначения.

Материалы и методы. На основе анализа индивидуальных программ реабилитации, разработанных медико-социальными экспертными комиссиями 19 областей Украины, рассчитаны показатели потребностей участников антитеррористической операции с инвалидностью вследствие соматической патологии в технических средствах реабилитации и изделиях медицинского назначения.

Результаты. В структуре мероприятий медико-социальной реабилитации участникам антитеррористической операции с инвалидностью рекомендации по техническим средствам составили 2,3 \%, медицинским изделиям - 0,1\%. Всего было назначено 327 рекомендаций по техническим средствам (в среднем на одного человека - 0,17) и 31 рекомендацию по медицинским изделиям $(0,016)$. Среди технических средств наибольшей была потребность в средствах передвижения и протезных изделиях; у лиц старше 60 лет и представителей I группы инвалидности; в Тернопольской области и г. Киеве; при болезнях костно-мышечной и нервной систем. Среди медицинских изделий наибольшая потребность в гигиенических средствах для ухода, наборах для аортокоронарного шунтирования; у больных молодого возраста и лиц с инвалидностью I группы; в Ивано-Франковской области; при болезнях уха и сосцевидного отростка.

Выводы. Определение особенностей потребностей участников антитеррористической операции с инвалидностью вследствие соматической патологии в технических средствах реабилитации и изделиях медицинского назначения в зависимости от возраста, тяжести инвалидности, вида средства (изделия), региональной принадлежности является организационно-методической основой для усовершенствования системы медико-социальной реабилитации таких лиц как в целом, так и на региональном уровне.

КЛЮЧЕВЫЕ СЛОВА: лица с инвалидностью; участники антитеррористической операции; соматическая патология; технические средства реабилитации; изделия медицинского назначения; потребности.

\section{THE NEEDS OF PARTICIPANTS OF THE ANTITERRORIST OPERATION WITH DISABILITIES DUE TO SOMATIC PATHOLOGY IN TECHNICAL MEANS OF REHABILITATION AND MEDICAL PRODUCTS}

O. B. Yavorovenko ${ }^{1}$, N. M. Belyayeva ${ }^{1}$, I. V. Kurylenko , L. V. Tomaschuk ${ }^{1}$, M. F. Yavorovenko ${ }^{2}$, G. V. Pavlichenko ${ }^{3}$

${ }^{1}$ Research Institute of the Rehabilitation of Disabled of M. Pyrohov Vinnytsia National Medical University, Vinnytsia, Ukraine

${ }^{2}$ City Clinical Hospital No. 3, Vinnytsia, Ukraine

${ }^{3}$ Vinnytsia Regional Center of Medical and Social Expertise, Vinnytsia, Ukraine

Purpose: to determine the needs of participants of the antiterrorist operation with disabilities due to somatic pathology in technical means of rehabilitation and medical products.

Materials and Methods. Based on the analysis of individual programs of rehabilitation developed by medical and social expert commissions of 19 regions of Ukraine, indicators of needs participants of the antiterrorist operation with disabilities due to somatic pathology in the technical means of rehabilitation and medical products were calculated.

Results. In the structure of measures for medical and social rehabilitation for participants of the antiterrorist operation with disabilities recommendations for technical means made $2.3 \%$, for medical products $-0.1 \%$. In general 327 recommendations were assigned for technical means (on average, 1 person had 0.17 ) and 
31 recommendations for medical products (0.016). Among the technical means the needs was greatest for means of locomotion and prosthetic products; for persons over 60 years of age and with disability group I; in the Ternopil region and in Kyiv; for diseases of the bone and muscular system and nervous system. Among the medical products the needs was greatest in hygienic care products, sets for aorta-coronary artery bypasses; in young patients and persons with disability group I; in the Ivano-Frankivsk region; for diseases of the ear and mastoid.

Conclusions. The analysis of specific features of the needs of technical means of rehabilitation and medical products in participants of the antiterrorist operation with disabilities due to somatic pathology depending on age, severity of disability, type of the mean or product, regional affiliation is organizational a methodical basis for improvement a system of medical and social rehabilitation of the such disabled both in general and at the regional level.

KEY WORDS: persons with disabilities; participants of the antiterrorist operation; somatic pathology; technical means of rehabilitation; medical products; needs.

Рукопис надійшов до редакції 10.09.2018 p.

\section{Відомості про авторів:}

Яворовенко Оксана Борисівна - завідувач організаційно-методичного відділу НДІ реабілітації осіб з інвалідністю ВНМУ імені М. І. Пирогова; тел.: +38(0432) 51-12-60.

Беляєва Наталія Миколаївна - кандидат медичних наук, завідувач відділу експертних досліджень НДІ реабілітації осіб з інвалідністю ВНМУ імені М. І. Пирогова; тел. +38(0432) 51-11-17.

Куриленко Ірина Володимирівна - кандидат медичних наук, завідувач поліекспертного відділення НДІ реабілітації осіб з інвалідністю ВНМУ імені М. І. Пирогова; тел.: +38(0432) 51-11-17.

Томащук Людмила Володимирівна - завідувач клініко-біохімічної лабораторії НДІ реабілітації осіб з інвалідністю ВНМУ імені М. І. Пирогова; тел.: +38(0432) 51-11-23.

Яворовенко Микола Феодосійович - завідувач відділення «Хоспіс» Вінницької міської клінічної лікарні № 3; тел.: +38(0432) 60-58-12.

Павліченко Галина Володимирівна - голова кардіологічної МСЕК Вінницького обласного центру медикосоціальної експертизи; тел.: +38(0432) 69-70-43. 